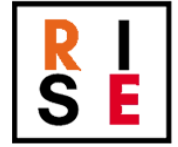

International Journal of Sociology of Education

\section{Hipatia Press}

www.hipatiapress.com

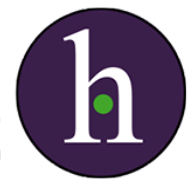

Instructions for authors, subscriptions and further details:

http://rise.hipatiapress.com

\title{
Trust in Pandemic-Induced Online Learning: Competitive Advantage of Closure and Reputation
}

Janet M. Arnado ${ }^{1}$

Ronaldo F. Jabal ${ }^{1}$

Mary Rose Jean Andrada Poa ${ }^{1}$

Teofilo C. Viray ${ }^{1}$

1) De La Salle University, Manila, Philippines

Date of publication: June $25^{\text {th }}, 2021$

Edition period: June 2021-October 2021

To cite this article: Arnado, J.M., Jabal, R.F., Poa, M.R.J.A. \& Viray, T.C. (2021). Trust in Pandemic-Induced Online Learning: Competitive Advantage of Closure and Reputation. International Journal of Sociology of Education, 10(2), 192-217. http://doi.org/10.17583/rise.2021.7088

To link this article: http://dx.doi.org/10.17583/rise.2021.7088

PLEASE SCROLL DOWN FOR ARTICLE

The terms and conditions of use are related to the Open Journal System and to Creative Commons Attribution License (CC-BY) 


\section{Trust in Pandemic-Induced Online Learning: Competitive Advantage of Closure and Reputation}

Janet M. Arnado

De La Salle University

Mary Rose Jean Andrada Poa

De La Salle University
Ronaldo F. Jabal

De La Salle University

Teofilo C. Viray

De La Salle University

(Received: 20 November 2020; Accepted: 12 April 2021; Published: 25 June 2021)

\section{Abstract}

As a response to the Philippine government's prolonged community quarantine measure to tackle the coronavirus outbreak, educational institutions have shifted their mode of teaching and learning towards distance education despite resistance from various sectors. This paper examines the ways an educational provider taps elements of its social capital such as closure and reputation, to establish enforceable trust from clients and their network to enroll in online learning; in addition, it explores the factors that clients consider in deciding to enroll their children in online distance learning. This study is informed by James Coleman's and Ronald Burt's conceptions of closure, trust, and reputation. It employs a case study approach, focusing on a Philippine Catholic parochial high school. Results show that closure is demonstrated through the school's dense social network with parents, students, and the community through the Catholic church. Closure and the school's intergenerational and social reputation facilitate the creation of trust, which increased senior high school enrolment, contrary to the pattern of private schools closing down due to insufficient enrolment. This study contributes to the literature in online distance education, by focusing on aspects of the social structure that function as resources for people and organizations to achieve their interests.

Keywords: social capital, online distance learning, Philippines, COVID-19 


\section{Confianza en el Aprendizaje en Línea Inducido por Pandemia: Ventaja Competitiva del Cierre y la Reputación}

Janet M. Arnado

De La Salle University

Mary Rose Jean Andrada Poa

De La Salle University
Ronaldo F. Jabal

De La Salle University

Teofilo C. Viray

De La Salle University

(Recibido: 20 Diciembre 2020; Aceptado: 12 Abril 2021; Publicado: 25

Junio 2021)

\section{Resumen}

Como respuesta a la prolongada medida de cuarentena comunitaria del gobierno filipino para enfrentar el brote de coronavirus, las instituciones educativas han cambiado su modo de enseñanza-aprendizaje a la educación a distancia a pesar de la resistencia de varios sectores. Examinamos las formas en que un proveedor educativo aprovecha elementos de su capital social, como el cierre y la reputación, para establecer confianza exigible de los clientes y su red para inscribirse en el aprendizaje en línea; explora los factores que los clientes consideran para decidir inscribir a sus hijos en el aprendizaje a distancia en línea. Este estudio se basa en las concepciones de James Coleman y Ronald Burt sobre el cierre, la confianza y la reputación, se emplea un enfoque de estudio de casos, centrando en una escuela secundaria parroquial católica filipina. El cierre y la reputación intergeneracional y social de la escuela facilitan la creación de confianza, lo que aumenta la matriculación en la enseñanza secundaria superior, contrariamente a la pauta de cierre de las escuelas privadas debido a la insuficiente matriculación. Este estudio contribuye a la literatura en educación a distancia en línea, al centrarse en aspectos de la estructura social que funcionan como recursos para que personas y organizaciones logren sus intereses.

Palabras clave: capital social, aprendizaje a distancia en linea, Filipinas, COVID19

2021 Hipatia Press

ISSN: 2014-3575

http://doi.org/10.17583/rise.2021.7088

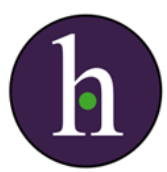




\section{Arnado, Jabal, Poa \& Viray - Pandemic-Induced Online Learning}

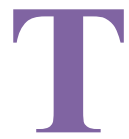

he Covid-19 pandemic has altered the everyday life of the world's people and acts as a threshold leading to the institutionalization of numerous technological innovations in our world, particularly in countries that are slow to change. Innovation is hindered by trust issues or fear of the unknown. However, the Covid-19 pandemic leaves countries with no option but to adopt to change.

In the Philippines, various degrees of community quarantine measures have been continuously imposed since March 2020, to maintain social distance and avoid mass gathering. Social institutions such as work, religion, and education have been reorganized to become largely home-based, mediated by the Internet. Filipinos below 18 and above 60 years old have been confined in their homes; violators were penalized through arrest, fines, or community service (Caliwan, 2020; Recuenco, 2020).

In compliance with the government's policy on social distancing and restrictions on mass gatherings, the Department of Education prohibited inperson classes and imposed distance learning as the new modality for instruction during the pandemic (DepEd, 2020). This is composed of three types: modular distance learning, online distance learning, and television/radio-based instruction (DepEd, 2020). Most public schools adopted remote learning through self-learning modules, delivered to and collected from the students' homes by the teachers or parents on a weekly basis. Some universities, on the other hand, shifted to full online distance learning immediately after the start of community quarantine (CHED, 2020). Other private schools opened the new academic year in July to August using online platform (Magsambol, 2020; Santos, 2020). In online distance learning, teachers and students hold synchronous or asynchronous classes through a learning management system.

Online classes have been offered for decades in many countries, but they never became the mainstream mode of learning. The Covid-19 pandemic succeeded in institutionalizing online learning what many years of online education failed. Online learning solves the problem of disruption in education during the pandemic. It provides continuity and enables the students to complete their education within their target time frame while having interaction with teachers and classmates in a virtual setting. It keeps them closer to their achievement of human capital (see Becker, 1993). This mode 
of learning, however, is highly challenging. It exacerbates the inequities in access to learning in the country (Palatino, 2020; Santos, 2020). Moreover, it requires investments in infrastructure, such as internet connectivity, learning management systems, and learning modules, among others. Students need connectivity, computer, and space conducive for learning at home - all seem to be absent or limited in most households in the Philippines. The current network infrastructure in the country is incapable of providing a stable internet connection especially in low-income rural slums and geographically isolated areas (Braid, 2020; Casal, 2020). For families who can afford online learning for their children, a primary concern is whether schools can deliver the same quality of education provided in the face-to-face setting.

In this paper, we employ social capital theory to analyze the role of closure, reputation, and trust in the competitive advantage of private schools that continue to thrive in this new, albeit temporary, condition. It examines the ways closure and reputation facilitate a school's trustworthiness which marks its competitive advantage over other schools. It also describes the factors that middle-class clients consider in deciding to enroll their children in online distance learning. In this case, the benefit of the organization's trustworthiness is the retention of students despite the shift to a fully online mode of delivery. Private schools depend on tuition fees, so retention of students means continuity of school operations. On the part of the clients, the advantage is the non-disruption of their children's education or continuity in human capital formation.

There exists a burgeoning body of research in online distance learning that focuses on the structure and process of its implementation in various countries, including the problems and gains that students, teachers, and parents derive from this new platform of education (i.e., Dhawan, 2020; Adnan \& Anwar, 2020; Putri et al., 2020). Our study contributes to and extends from this body of literature by focusing on certain aspects of the social structure which function as resources people and organizations can use to achieve their interests. It focuses on aspects of social structure that facilitate trust in online learning through trust in the organization that delivers it. The socio-economic conditions of families that result from the pandemic is outside the scope of this study.

In his theory of social capital, Coleman (1988) argued that closure or 
strong social ties in the social structure facilitates trust. In addition to closure, reputation likewise results in trust, which happens when a person's behavior is predicted to be "consistent with shared beliefs" (Burt 2005, p. 107). Trust is an important element in social capital because it is the basis for building a relationship when "contractual terms are incompletely specified" (Burt, 2005, p. 93). Furthermore, Burt (2005) posits, "The more unspecified, taken-forgranted, the terms, the more that trust is involved. You anticipate cooperation from the other person, but you commit to the relationship before you know how the other person will behave" (p. 93). Full online learning alters how formal education has been done for centuries. Its contractual terms are incomplete as rules are evolving with the learning experience of the institutions practicing it. Trust is therefore involved in this transition.

In what follows, we discuss the theoretical underpinnings of this paper, where we elaborate on the notions of closure, reputation, and trust in social capital. We also review the empirical literature on online learning. After which, we describe the details related to the qualitative methods employed in this study, in which we focus on a case: a Catholic parochial high school in the Philippines that offered online distance learning modality to middle-class students. Finally, we present the results, discussion, and conclusion. In this study, the shift to online learning depicts the following: "a world in which reputation replaces authority, pursued opportunity replaces assignment, and reward is associated with competitive advantage in a social order of continuous disequilibrium" (Burt, 2005, pp. 7-8).

\section{Closure, Reputation and Trust}

This paper is framed within the various perspectives of social capital, particularly the concepts of closure, reputation, and trust in Coleman's (1988) and Burt's $(2000,2005)$ works. We situate education as human capital, more specifically as cultural capital (Bourdieu, 1986) in its institutionalized state: a diploma that leads to economic and social rewards. Embedded in the social structure of relations, social capital is used in this paper as a metaphor for competitive advantage. Coleman (1988, p. S105) puts it this way: "All social relations and social structures facilitate some forms of social capital; actors establish relations purposefully and continue them when they continue to 
provide benefits."

In the context of social relations, Coleman introduced the concept of closure which facilitates effective norms and trust. Portes (1998, p. 6) defines Coleman's concept of closure as "the existence of sufficient ties between a certain number of people to guarantee the observance of norms." In addition to norms, closure also facilitates trustworthiness. Coleman (1988) posits:

Closure of the social structure is important not only for the existence of effective norms but also for another form of social capital: the trustworthiness of social structures that allows the proliferation of obligations and expectations. Defection from an obligation is a form of imposing a negative externality or another. Yet, in a structure without closure, it can be effectively sanctioned, if at all, only by the person to whom the obligation is owed. Reputation cannot arise in an open structure, and collective sanctions that would ensure trustworthiness cannot be applied. Thus, we may say that closure creates trustworthiness in a social structure (pp. S107-108).

Coleman (1988) emphasized the role of closure in the social structure in facilitating trust, trustworthiness, and competitive advantage: a group with "extensive trustworthiness and extensive trust is able to accomplish much more than a comparable group" without them (Coleman, 1988, p. S101). Trustworthiness among group members is essential for an institution to exist.

The literature describes closure in different terms, including "cohesive groups, strong cultures, teams, and cults" (Burt, 2005, pp. 12-13). These similar concepts, according to Burt, are associated with social control through reputation-protection, making individuals in this tightly knit network prone to be trusted. We incorporate reputation in our analysis as an aspect of closure and social control. It works as capital, an investment that yields revenues (Voswinkel, 2011) such as trust. Voswinkel (2011) defines reputation as follows:

Reputation is one aspect of esteem. It designates a positive image that is acquired and conferred for a limited time and for a specific quality or achievement; it gives rise to influence and is capable of inspiring confidence. We speak of reputation when recognition reaches beyond personal contacts, and hence has public validity and does not rest on 


\section{Arnado, Jabal, Poa \& Viray - Pandemic-Induced Online Learning}

direct personal acquaintance (p. 35).

As Voswinkel describes above, reputation involves public validation and is beyond personal relationships. Reputation is defined by people who monitor and discuss the ego's behaviour, and consequently have control over behaviour (Burt, 2005). For Burt, the basis for good behavior is the protection of reputation. As people and organizations protect their reputation, reputable individuals and organizations are trustworthy. Those with reputation tend to protect it by avoiding behaviors that are detrimental to their reputation.

When classes in Philippine universities and schools were called off in March 2020 and some schools continued by shifting to online learning, there was a national clamor against it. It was based on the argument that 'no student should be left behind.' In addition, there was a low level of trust in the capability of educational institutions to operationalize fully online learning in the same quality as in-person education. This was based on the view that most schools were unprepared, and students did not have the resources to study online. Aside from connectivity issues, many students lack a learning environment in their homes.

In the context of this paper, a school that can establish trustworthiness is more likely to accomplish the goals of the new mode of learning than other schools with little trust from their clients. In the same way, middle-class parents who find trust in their children's school are more likely to proceed with an online mode of learning than those without trust in the school.

\section{Studies on Online Learning}

Online learning, especially fully online learning, is a huge transformation to the normative face-to-face education that withstood the test of time. This change, therefore, brings with it financial, technological, pedagogical, emotional, social, and labor dimensions, among others. All of these factors interconnect as the boundaries in our everyday lives are disappearing.

One major issue in online learning is whether it could deliver the same quality education as face-to-face learning. A study in Thailand investigated the key determinants of quality education of upper-secondary schools in an online learning set up and concluded that the transformational leadership of 
the school principal, teacher quality, and school facilities determine the quality of education (Pootrakul, 2014). A similar study (Allen et al., 2003) identified the teacher's qualifications as the first consideration in ensuring quality education. It includes the instructors' understanding of their roles as online educators and ability to adjust their attitudes for this role change; mastery in design and delivery strategies, techniques, and methods for teaching online courses. In addition to the teacher factor is the vital role of administration in providing all the needs to ensure quality online instruction. Like in the traditional classroom, online education promotes students' critical thinking skills, deep learning, collaborative learning, and problem-solving skills which can be done through exploration, reflection, and discussion, and ultimately lead to students' deeper learning (Ascough, 2002).

Technological preparedness is important as well; it includes the availability of technological infrastructure, the skills to use this technology, and the connectivity to access this technology online. Poor connectivity in developing countries makes it difficult to achieve the desired results of online learning (Adnan \& Anwar, 2020). In Adnan and Anwar's (2020) study, Pakistani university students identified as major problems in online learning the lack of access to high-speed internet and delayed response time of their professors. Likewise, Indonesian teachers and pupils in the primary grade levels cited a lack of technology skills and higher internet bills as constraints to online learning (Putri et al., 2020).

Online learning has emotional, social, pedagogical, and labor dimensions. Research shows that online learning hampers communication between the learner and the educator because direct communication and human touch are lost (Dhawan, 2020), communication and social interaction are limited (Putri et al., 2020), and response time is delayed as shown by Adnan and Anwar's (2020) study above. Another similar study (Pardanjac et al., 2009) documented the learners' confusion, anxiety, and frustration from lack of fast feedback and unclear instructions of the course's website or email messages. Students are longing for voice-based instructions to complement the written ones (Allo, 2002). Unlike instruction in the traditional classroom, Palloff and Pratt (1999) see that greater attention must be paid to online distance learning to the development of a sense of community within the virtual classroom for students' learning to be successful. 


\section{Arnado, Jabal, Poa \& Viray - Pandemic-Induced Online Learning}

Online learning is labor-intensive because teachers have to prepare teaching methods and learning materials appropriate to online learning, attend to parents' and students' questions and concerns, as well as coordinate with other teachers and administration (Suryaman et al., 2020; Putri et al. 2020). Parents have to devote more time to assist their children's learning process (Suryaman et al., 2020; Putri et al., 2020). This takes away from the parents' time for work and rest.

\section{Methods}

This study employed a case study approach and is partly autoethnographic because one of the researchers is a member of the institution being examined. We applied case study to examine "a real-life, contemporary bounded system (a case)...over time, through detailed, in-depth data collection involving multiple sources of information" (Creswell \& Poth, 2016, p. 96). For our case, we selected one Catholic educational institution in Metro Manila. We name the school, St Mary's Academy. This institution is a 100-year-old Catholic high school that, according to its vision, promotes local culture and heritage and envisions to be the center for integral faith formation, academic excellence, and servant-leadership for the school community. It offers primary and secondary education to middle-class students. We chose St. Mary's Academy as our case because this parochial school has already established an online distance learning continuity plan in its previous academic years.

This partly autoethnographic case study consisted of interviews, participant observation, and document review. We interviewed the school administrator and ten parents or guardians of currently enrolled Grade 12 students in September 2020. Parents and guardians were recruited via virtual snowball sampling. Interviews were conducted online via Google Meet, Zoom, and Facebook Messenger.

The interview guide consisted of closed- and open-ended questions. These questions include the following: socio-demographic and economic characteristics, conceptions about quality education, factors being considered before enrolling their children in online education, and things the school needs to do to gain parents' trust in online education.

The interviews were recorded, transcribed, and underwent thematic coding 
based on the research questions. In addition to themes, outliers were noted. Interview data were triangulated with school documents and statistics. Of the ten parents interviewed online, eight are female and two are male; all are married and Catholic. They are professionals engaged in education (2), accounting (1), information and technology (1), photography (1), and business (3). Two are housewives. Students enrolled in this school are presumed to be members of the middle class based on the school's tuition fees.

One of the researchers, who is a member of the school administration, conducted participant observation. Through our participant-observer, we obtained an insider perspective of the institution and had access to the school website and documents, such as enrolment records, mission-vision, strategic goals, and continuity learning plan. These documents were reviewed and integrated into the analysis.

Prior to the conduct of the study informed consent was obtained from the school administration and the parent interviewees. Participants were informed about the purpose, terms, duration, anonymity, and confidentiality of the study, including the right to decline to answer any question, leave the conversation, or ask to end to interview at any point. In this paper, the school and the informants are assigned pseudonyms to protect the school and informants' privacy.

\section{Results}

The case of St. Mary's Academy is an example of a private educational institution that survives the altered mode of education from in-person to an online platform during the Covid-19 pandemic. As our framework suggests, this happens because of the apparent social capital in the social structure, as manifested in closure (ties that bind) that facilitates the enforcement of trust. In turn, this trust generates sufficient enrolment for the school to continue its tasks. Below we provide details of the case. First, we describe how closure is manifested in the social structure of the school, and how the school enhanced its trustworthiness even before the pandemic. Then we discuss the parents' side of the situation, detailing their views about online learning and their trust in the school as the basis for their decision to enroll their students. 


\section{Arnado, Jabal, Poa \& Viray - Pandemic-Induced Online Learning}

\section{Closure in the Structure}

Closure in the social structure facilitates the enforcement of new norms and trust in the new learning modality. As one of the older Catholic schools in Metro Manila, St. Mary's Academy has built a positive reputation, spanning generations, embedded in its dense network within the community through the church. As informant Rose reveals: "There is also a [good] quality of education in the school if [it has] a good reputation. And it will give a high standard for the school."

Within the school, there is a tight network among parents, teachers, and school administrators. Beyond the school population, St. Mary's reaches out through its connection with the church that brings the community together regularly.

Parent-Teacher Association (PTA) connects each parent to other parents and the school administration through the teachers. Needs are communicated and addressed through the PTA. In addition to the PTA, parents have formed associations per grade level. It is called Bukluran Parents Group. In this group, parents regularly share their concerns through social network channels, such as Facebook Messenger.

Beyond the members of the school community, St. Mary's Academy used its network resource as a parochial school by promoting its new online education program in the Catholic Church after Sunday masses. This is an effective form of campaign in terms of reach, as most Filipinos are Catholic and religious. This sense of community manifested in associations and religious activities is a feature of a dense network which Coleman (1988) described. In his study, Coleman (1988) found that membership in communities reduces the number of dropouts among students, especially in religious schools.

Parent-informants in our study cited the dense network that their children have built with their classmates and teachers. Because they have formed a bond, especially with their classmates, children prefer to continue with their studies and remain in the same school. Parents consulted and respected their children's preferences. Rita, who said that transferring their child with just one more year left in senior high would be a waste, stressed, 
We need to give our children a voice. We never had problems with St. Mary's Academy. The tuition may be expensive, but [the teachers] are doing everything to teach my children properly even through online learning...We need to ask the kids. I will ask my kids if they want to stay with St. Mary's Academy even if it's still online distance learning after the pandemic. I prioritize where they will be happy and content. That's important to me. Our role as parents is to support them. Everything can be discussed.

The parents' close ties and experience with the school generated sufficient enforceable trust for them to venture into an emerging norm of online learning.

\section{Trustworthiness}

Closure creates trust. St. Mary's Academy has established its trustworthiness not only towards its existing students but also to the community at large. It is manifested in the remarkable increase of enrollees in senior high school. From 98 students in the previous year, the population increased to 162 during the pandemic, when a decline is expected and experienced by many schools. The increase may be due to parents giving preference to their children in senior high school to avoid delaying their completion.

Overall, there is a 10 percent decline in enrolment at all levels of St. Mary's, from 1,653 in the previous year to 1,492 this academic year. This is a manageable number compared to other schools. Low enrolment resulted in the closure of 860 private schools in the Philippines, affecting more than 60,000 students and teachers (Hernando-Malipot, 2020).

St. Mary's relatively good performance in retaining and attracting students in its online distance learning program did not happen by accident. We argue that it is due to the school's trustworthiness, embedded in the social structure. The school began enforcing trust in its online learning program two years before the pandemic kept the students in their homes. It implemented the Blended Learning Modality Program for senior high school. In this blended program, a four-unit course constituted three hours of face-to-face instruction and one hour of online distance learning. The increase in senior high school enrolment may be explained by the established online learning program in the school. The school's experience may have influenced parents' decisions to 


\section{Arnado, Jabal, Poa \& Viray - Pandemic-Induced Online Learning}

enroll in their school.

The school principal attributed the increase in enrolment to several factors. One is the investment in online distance learning program infrastructures such as LMS or Learning Management System and digital platforms. Another factor is the online distance learning preparations for teachers and clients. These preparations include module development and seminar workshops for teachers and clients. These new initiatives are supplemented with low tuition fees in comparison with other neighboring private basic school institutions. To further entice students and parents, the school gave tablets to the first 100 enrollees.

Finally, the school principal attributed their success to the effective marketing and strategic plans of the enrolment communication team. To market their online program, the team conducted a school caravan to all Catholic schools in the city and made effective use of social media. They communicated their school's preparedness for online mode of learning through Facebook, Instagram, and Twitter. The school also used Google's video conferencing application to conduct parents' and students' orientations on online distance learning.

For the current school year, the school has implemented the Modified Online Distance Learning (MODL). MODL is designed not just as a response to the national educational crisis, it is also meant to be a flexible digital learning program that ensures continuity of learning from the safety of every child and teacher's homes, with no face-to-face class for the duration of the current school year. The school has three learning management systems (LMS): Google Classroom, Frontlearners, and Scholastic Prime Reading Program. It has an in-house e-learning management team that runs the three LMS collaboratively.

The school administrators closely monitored the Department of Education's directives. They consulted with academic and industry practitioners and the school's stakeholders to improve their MODL program like The International Society for Technology in Education's (ISTE) standards for students and teachers. ISTE is the foremost international organization in teaching technology in the classroom. There are 7 ISTE standards that this Catholic parochial school strives for students to meet beginning this school year: empowered learner, digital citizen, knowledge 
constructor, innovative designer, computational thinker, creative communicator, and global collaborator.

Given lingering doubts and reservation of parents, school administrators were pressed to operationalize online distance learning, to ensure quality education through the new approach. They faced the challenge of convincing their clients (the parents or guardians) to invest in continuing education despite reservations on the non-traditional modality. The achievement of formal education as an institutionalized status is an important value among Filipinos. Families invest in education as human capital to achieve returns that facilitate in maintaining or improving access to long-term physical and social capitals (Becker, 1993; Bourdieu, 1984; Coleman, 1988; Wenwen, 2017).

\section{Clients' Trust}

The school's enforcement of trust is one side of the narrative; equally important is the clients' trust in the school to provide quality online education to their children. Building clients' trust is an indication of the school's success in enforcing trust in them as a provider. This is what Coleman refers to as enforceable trust, a key factor in network closure. The parents cited that St. Mary's teachers have the proper training and capacity to teach using the online distance mode of learning.

We know St. Joseph will not adopt online learning if they are not ready. We also like that our principal's concern is always the readiness of the teachers. We know the school provides training to teachers. We saw how the school values quality education. - Parent Rosa

Of course, we value the capacity of teachers and schools in implementing online learning. We know teachers are knowledgeable in computer technologies. We also know that the school has complete facilities for online learning. - Parent Ruby

Parents and guardians expressed doubts and reservations in online learning as the primary mode of education. They worried about the potential impact of online learning on the learning curve of their children, due to the absence of instant validation, interaction with peers, and a sense of community provided 


\section{Arnado, Jabal, Poa \& Viray - Pandemic-Induced Online Learning}

in face-to-face mode learning. Parents Ruby, Rose, and Rica were apprehensive that the absence of physical supervision from the teachers will negatively impact learning. They stressed that the students' concentration is significantly reduced when studying. They also cited the teachers' inability to actively check the students' performance in online learning. Parent Ruffa said,

I still like face-to-face because we can readily see if the students are attentive or not. Teachers can easily detect if students are focused on the instruction, especially what they are teaching especially when they jot down notes, and when we can see teachers writing on the board as they discuss lessons.

Some parents, on the other hand, raised the role and efficacy of parents in helping deliver online learning. Without face-to-face education, parents are obligated to facilitate learning.

Parents have roles in student's learning activities. Even if my child is in grade 12 and is already considered an adult, parental guidance is still needed to ensure he is focused on his online class. For me, parents need to monitor the students' online activities. - Parent Ruffa

Despite their apprehensions, parents stressed their desire to give the best for their children. Hence, they look for educational institutions that provide quality education. Parents have different conceptions on what constitutes quality education; yet, they tend to agree on two indicators: (1) capability of the educators in online teaching; (2) capability of the school administration to provide the online learning platforms and address the teachers' and learners' needs. Thus, in deciding which school to enroll their children in, they considered the school's capability to deliver online learning.

[The school] provides training for their teachers. Our principal is kind and dedicated to teaching. I also believe that St Mary's can [implement] the instructions of DepEd [Department of Education]. - Parent Rica.

I have decided that even if the learning will be done online, I will enroll my kid in St. Mary's. I have big confidence that they are ready and they have the capacity. I have seen that they deliver quality education. They 
are really good. - Parent Rose

In the end, parents enrolled their children at St. Mary's because they trusted the school. We examine several bases of this trust associated with closure, or their strong ties with the school. These include the school's reputation, client experience, and school's preparedness.

\section{School Reputation and Client Experience as Bases of Trust}

Parents considered the school's reputation as one of the bases of their trust in the school. This is partly what Bourdieu (1986) refers to as social capital being part of a collective of resources, both actual and expected, linked to a durable network with a somewhat institutionalized social structure that is borne out of mutual recognition by its members. Coleman (as cited in Portes, 1998) called this a function of social capital that facilitates motivated actions by actors. He clearly emphasized that reputation cannot arise in an open structure. Hence, parents citing reputation as a basis of trust indicates their being part of a dense network where brand and image are key to ensure closure.

St. Mary's Academy is a century-old institution with some of the interviewees being alumni or employees of the school. The school's reputation for quality education spans generations in most of the families that we interviewed. The trust could also be observed in the parents' confidence that the school itself will improve its services even without external enforcement to maintain its reputation. Parent Rose confidently said, "I have big confidence that the school is ready and has the capacity. I have seen that they deliver quality education. They are really good".

Even parents vehemently opposed to online learning enrolled their children at St. Mary's, because it is known to provide quality education. The school's reputation made them decide.

...St. Mary's Academy is a prestigious school. They are highly reputable. Students derive honor for themselves when they graduate from this school. That's why we continue to enroll our kids in this school despite the current method of learning. - Parent Rico 
In this situation, quality education is expressed in terms of reputation, drawn from the parents' strong historical ties with the school. Coleman, Lin, Ensel, Vaughn (as cited in Portes, 1998, p.13) called this "strength of strong ties" in a dense social network that ensures bounded solidarity and maximum gains for the actors. Coleman (as cited in Portes, 1998) asserts that reputation cannot arise in an open structure. St. Mary's reputation served to close the network that helped ensure enrollment.

\section{Preparedness of the School}

Because of the good education the school had provided in blended learning, parents supposed that their children would continue to get the education they deserve in an online distance learning environment from St. Mary's. They cited the readiness of the school facilities and the openness of the school administration. Parents positively perceived the numerous actions and preparations made by the school administration to implement the new method of learning. Parents Roma and Rica expressed no regrets in enrolling their children at St. Mary's despite their reservations.

I can see that St. Mary's Academy is doing its best to provide quality education to all students despite the implementation of online learning. They adjusted school activities because they are only after the welfare of students. - Parent Roma

Parents noted several other bases of their trust in the school. For example, parents enrolled their children in St. Mary's because the teachers are wellequipped for the transition. They cited teachers' training to improve their capacity.

We know St. Mary's will not adopt online learning if they are not ready. We also like that our principal's concern is always the readiness of the teachers. We know the school provides training to teachers. We saw how the school values quality education. - Parent Rosa

One parent received feedback from their children about the preparedness 
of the teachers.

I received good feedback from my kids. I can also see that the teachers are very concerned about their students. I also noticed that the interaction between teachers and students, although online, remained intact. I can see that the students are being guided. That's what I really liked. - Parent Rico

Additionally, parents find that the school provides reliable technology, including various online tools such as Google Classroom, Google Meet, and Blackboard. The school also communicates efficiently with them, giving updates on their children's lessons and schoolwork. Constant communication from the school eases their worries.

The school planned and prepared for this school year. There are some schools that still do not have physical books until now, so parents keep going back to the school. St. Mary's Academy announced the date for book pickup. I only had to go once because the materials were already complete. - Parent Rita

An important element of closure is access to information. Coleman (1988) argues that when people are not greatly interested in current events but are interested in being informed about important developments, there is a marked increase in social capital. Access to information about the school's preparation for online learning contributed to parents' decision to enroll their children in this school. In the case of St. Mary's Academy, information comes from their direct knowledge of the school's preparation based on the school's announcements and their children's experiences.

The decision to enroll despite opposition to change aligns with avoidance of sanctions as Coleman pinpointed. Some parents articulated that they did not want their children to be left behind by their classmates who continue to study and that finishing Grade 12 is crucial to the future of their children. The feeling of not wanting to "be left behind" works in what Coleman described as a sanction in closure. This sanction associated with being left behind pushes people in a dense network to conform to the new norm. Coleman furthered that when an effective norm does exist, it constitutes a powerful form of social 


\section{Arnado, Jabal, Poa \& Viray - Pandemic-Induced Online Learning}

capital. He stressed that norms in a community that support and provide effective rewards for high achievement greatly facilitate tasks.

\section{Discussion}

The goal of this paper is to examine the role of closure, trust, and reputation in the competitive advantage of private schools in implementing fully online distance learning during the COVID-19 pandemic when many schools closed due to inadequate enrollment. We wanted to identify the school's pull factors that entice financially capable families to continually patronize it despite a 360-degree turn-around in the mode of teaching and learning. We employed James Coleman's theory of social capital, particularly the notion that closure brings about trust, which makes social relationships sustainable even in challenging conditions such as the Covid-19 pandemic. In the case of St. Mary's Academy, the strong ties that bind families and the school together for generations and through the church facilitated and sustained the families' trust in the school. These ties comprise a network of parents, teachers, administrators, and the church composed of those belonging inside and outside the school.

This study affirmed the theorizing on the role of the strength of ties in a dense network as a source of social capital (Coleman, 1988; Portes, 2009). It confirms that closure influences the achievement of trust through the performance of normative behavior. Utilizing reputation in achieving trust requires an investment of consistent practices over an extended period. Interestingly, the study expanded theorizing on social capital by showing how reputation can influence the decision of financially capable parents to enroll their children despite reservations and lack of trust in online learning.

How does closure facilitate trust? Aside from its capacity to sanction, closure or closed network enabled an exchange of information and opinion, which resulted in a collective opinion based on trust to continue their children's education in an online setup. Trust resulted in parents' decision to allow their children to stay in the school, even with a more ambiguous learning platform. They stayed with the school regardless of their trust in the capability of online technology to facilitate learning for their children. What these families trust is the school's capacity to deliver its promise of quality 
education in an online platform.

The paper explored the parents' definition of quality education in the context of online learning. The parents defined quality education as a factor of (1) teacher capability to be enablers of learning, knowledge experts, and students' mentors; (2) school's capacity to train its teachers, establish a sense of community, communicate effectively to its clients, and enact decisions based on national policies and contextual needs of its clients; and (3) teacher and school's capacity to harness technology to ensure the student's positive experience in learning online. Other critical factors in quality education included stability of the internet connection, the school's capacity to provide support to students without access to technology, continuous training for the faculty and staff, and the coordination with the students' parents. Evidently, parents value the resources and capability of the school which is contributing to their trust in online education being offered by the St. Mary's Academy. These resources are made available because of higher tuition fees from the middle- to upper-middle-class parents that send their children to the school.

Through various channels of communication available within the social network, the school communicated to the parents and the community its capability to meet quality education in an online setting. Aside from new preparations for fully online delivery, the school also showcased its experience in blended education given to senior high school before the pandemic.

As the provider of social capital, St. Mary's Academy has established its reputation of quality education by consistently imparting positive learning experiences throughout its 100-year existence. This consistent performance has allowed the institution to also establish a sense of community with close ties among its clients - the parents and their children. As a result, the trust expressed in the form of continuous membership through enrollment was still achieved even if the method of service delivery was altered due to the pandemic. Despite a deep distrust in technology and the identified risks and challenges in online distance learning, parents still opted to enroll. The ensured enrollment is driven by their positive perception of St. Mary's Academy, their desire to retain their membership, and their experience of the school's efforts to improve online learning as a new modality. Trust, as noted earlier, is committing to a relationship before knowing "how the other 


\section{Arnado, Jabal, Poa \& Viray - Pandemic-Induced Online Learning}

person", or in this case, how the school, will behave (Burt, 2005, p. 93). The decision to enroll despite some doubts achieves legitimacy in the parents' minds because they are part of a dense network achieved through long-term exchange of experiences (see Coleman, 1988). The parents' trust in teachers and school administrators provides what Coleman (1988) noted as a temporary aspect to the nature of exchanges and continuity to the relationship.

An aspect of closure, reputation reinforces trust in the school. Most of our informants drew from what the generalized others say about the school as well as their own experience. These generalized others may include their parents, relatives, friends, and friends of friends. Closed network and reputation shape their trust in the school. A trusted person/organization draws others to join them into relatively unknown territory.

Using the experience in online distance learning of St. Mary's Academy as a case, we demonstrated the ways network closure facilitates clients' trust in the school. This study reinforces similar studies done on closure and trust, such as Coleman's study of rotating credit associations (Coleman, 1988).

\section{Conclusion}

This paper demonstrated how closure and reputation contribute to trust that influenced the decision of parents to remain in the school in an online learning modality during the pandemic. It shows the importance of building and sustaining relationships through formal and informal communication channels. While school preparedness should be the most important basis for trust, the way this preparedness is channelled based on one's reputation through a dense network is what facilitates trust. This analysis, however, is limited to resource-rich institutions and parents with the financial capability to pay for the tuition fees. It does not address the larger question of financial resources as a major reason for the low enrolment rate in general.

The use of network closure and trust can be extended to other studies on institutional transformations that happened due to Covid-19. It can explore trust in the digitalization of everyday life and includes the rise of other online practices, such as entrepreneurship, banking, administration, and even intimacies.

These findings also contribute to the literature providing empirical data to 
inform the Philippine education system of the inequities that are inadvertently caused by online learning to improve policy and practice. It provides schools with information on how they can improve their services to ensure quality education and increase enrollment. We would recommend a similar study to be conducted among parents and students enrolled in public schools where self-learning modules are primarily used. The research provides an opportunity for learning providers to assess their clients' expectations, the quality of social capital they have with their current clients and develop steps to achieve client trust in online distance learning during the pandemic.

\section{Acknowledgments}

We thank the principal of St Mary's Academy for allowing this study to be conducted among parents of enrolled students. We also like to thank the parents of the students for their time during the series of interviews conducted concerning the study.

\section{References}

Adnan, M., \& Anwar, K. (2020). Online Learning amid the COVID-19 Pandemic: Students' Perspectives. Online Submission, 2(1), 45-51. https://doi.org/10.33902/JPSP

Allen, I. E., \& Seaman, J. (2003). Sizing the opportunity: The quality and extent of online education in the United States, 2002 and 2003. The Sloan Consortium, Needham, Massachusetts. http://www.sloan-c.org Allo, M. D. G. (2020). Is the online learning good in the midst of Covid-19 Pandemic? The case of EFL learners. Journal Sinestesia, 10(1), 1-10. Retrieved from https://sinestesia.pustaka.my.id/journal/article/view/24 Ascough, R.S. (2002). Designing for online distance education: Putting pedagogy before technology. EBSCOhost database. Teaching theology and religion, 5(1), 17-29. https://doi.org/10.1111/14679647.00114

Becker, G. S. (1993). Human Capital A Theoretical and Empirical Analysis with Special Reference to Education (Third). The University of Chicago Press.

Bourdieu, P. (1984). Distinction: A Social Critique of the Judgement of 
214 Arnado, Jabal, Poa \& Viray-Pandemic-Induced Online Learning

Taste. London: Routledge.

Bourdieu, P. (1986). The Forms of Capital. In Handbook of Theory and Research for the Sociology of Education. J. Richardson (Ed.). (pp. 241-258). Westport, CT: Greenwood.

Braid, F. R. (2020, August 21). Distance education in these pandemic times. Manila Bulletin. Retrieved from

https://mb.com.ph/2020/08/21/distance-education-in-these-pandemictimes/

Burt, R. S. (2000). The network structure of Social Capital. Research in

Organizational Behavior, 22(2000).

Burt, R.S. (2005). Brokerage and Closure: An Introduction to Social

Capital. Oxford University Press.

Caliwan, C. (2020). Community service, fines for quarantine violators preferred $\mid$ Philippine News Agency. Retrieved from https://www.pna.gov.ph/articles/1114229

Casal, M. (2020). The Pandemic is Reshaping Education, Here's How the Philippines is Coping. Rappler. Retrieved from

https://www.rappler.com/brandrap/tech-and-innovation/coronavirusreshaping-distance-learning-education-philippines

Coleman, J. S. (1988). Social Capital in the Creation of Human Capital. American Journal of Sociology, 94, Supplement: Organizations and Institutions: Sociological and Economic Approaches to the Analysis of Social Structure (pp. S95-S120).

Commission on Higher Education (2020). Guidelines on the Implementation of Flexible Learning. Retrieved from https://ched.gov.ph/wpcontent/uploads/DRAFT-Guidelines-Flexible-Learning_for-PublicConsultation.pdf

Creswell, J. W., \& Poth, C. N. (2016). Qualitative Inquiry and Research Design: Choosing among five approaches. Sage Publications.

DepEd Order No. 012, s. (2020). Adoption of the Basic Education Learning Continuity Plan in the Time of COVID-19. Department of Education. Retrieved from https://authdocs.deped.gov.ph/depedorder/do_s2020_012-adoption-of-the-be-lcp-sy-2020-2021/

Dhawan, S. (2020). Online Learning: A Panacea in the Time of COVID-19 Crisis. Journal of Educational Technology Systems, 49(1) 5-22. 


\section{https://doi.org/10.1177/0047239520934018}

Hernando-Malipot, M. (2020). Over 60,000 Students, Teachers affected by Closure of 860 Private Schools. Manila Bulletin. Retrieved from https://mb.com.ph/2020/10/07/over-60000-students-teachers-affectedby-closure-of-860-private-schools/

Magsambol, B. (2020). DepEd: Private schools can start classes before October 5 using distance learning. Rappler. Retrieved from https://www.rappler.com/nation/private-schools-may-proceed-classesahead-october-5-using-distance-learning

Palatino, M. (2020, June 2). Pedagogy of the digitally oppressed. Bulatlat. Retrieved from https://www.bulatlat.com/2020/06/02/pedagogy-ofthe-digitally-oppressed/

Palloff, R.M., \& Pratt. K. (1999). Building learning communities in cyberspace: Effective strategies for online classroom. San Francisco, Jossey-Bass.

Pardanjac, M., Radosav, D., \& Jokic, S. (2009). Advantages and disadvantages of distance learning. MIPRO 2009 - 32nd International Convention Proceedings: Computers in Education. 4. 237-241. Retrieved from

https:/www.academia.edu/40409329/ADVANTAGES_AND_DISAD VANTAGES_OF_DISTANCE_LEARNING

Portes, A. (1998). Social Capital: Its Origins and Applications in Modern Sociology. Annual Review of Sociology, 24 (1), 1-24.

Portes, A. (2009). Social capital: Its origins and applications in modern sociology. Knowledge and Social Capital, 43-68. https://doi.org/10.1016/b978-0-7506-7222-1.50006-4

Pootrakul, P. (2014). Key Determinants of the Education Quality of Secondary Schools in Bangkok. School of Public Administration. National Institute of Development Administration 2014. Retrieved from http://libdcms.nida.ac.th/thesis6/2014/b186218.pdf

Putri, R. S., Purwanto, A., Pramono, R., Asbari, M., Wijayanti, L. M., \& Hyun, C. C. (2020). Impact of the COVID-19 Pandemic on Online Home Learning: An Explorative Study of Primary Schools in Indonesia. International Journal of Advanced Science and Technology, 4809-4818. Retrieved from 
216 Arnado, Jabal, Poa \& Viray-Pandemic-Induced Online Learning

https://search.bvsalud.org/global-literature-on-novel-coronavirus2019-ncov/resource/en/covidwho-830197

Recuenco, A. (2020). COVID Shield prefers community service, fine for curfew violators - Manila Bulletin. Retrieved from https://mb.com.ph/2020/09/02/covid-shield-prefers-communityservice-fine-for-curfew-violators/

Santos, A. (2020). In the Philippines, Distance learning reveals the digital divide | Heinrich Böll Stiftung | Brussels office - European Union. Heinrich Boll Stiftung. Retrieved from https://eu.boell.org/en/2020/10/06/philippines-distance-learningreveals-digital-divide

Santos, E. (2020). Private schools free to start distance learning classes before October 5 - DepEd. CNN Philippines. Retrieved from https://www.cnnphilippines.com/news/2020/8/15/private-schoolspandemic-class-opening-deped-.html

Suryaman, M., Cahyono, Y., Muliansyah, D., Bustani, O., Suryani, P., Fahlevi, M., \& Munthe, A. P. (2020). Covid-19 pandemic and home online learning system: Does it affect the quality of pharmacy school learning?. Systematic Reviews in Pharmacy, 11(8), 524-530. http://doir.org/10.31838/srp.2020.8.74

Voswinkel, S. (2011). Reputation: A sociological view. In Reputation Management (pp.31-45). Springer, Berlin, Heidelberg.

Wenwen, Z. (2017). School-family cooperation, social closure, educational equality and excellence: Evidences from China. Research in Educational Administration and Leadership, 2(2), 250-270. https://doi.org/10.30828/real/2017.2.6 
RISE-International Journal of Sociology of Education, 10(2) 217

Janet M Arnado is associate professor and chair of the Behavioral Sciences Department at De La Salle University, Manila, Philippines.

Ronaldo F Jabal is a PhD student at De La Salle University, Manila, Philippines.

Mary Rose Jean Andrada Poa is a PhD student at De La Salle University, Manila, Philippines.

Teofilo C Viray is a PhD student at De La Salle University, Manila, Philippines. 